\title{
The Taxation of Passive Foreign Investment Lessons from German Experience
}

\author{
MARTIN RUF \\ ALFONS J. WEICHENRIEDER
}

CESIFO WORKING PAPER NO. 2624

Category 1: Public Finance

APRIL 2009
An electronic version of the paper may be downloaded
- from the SSRN website: Www.SSRN.com
- from the RePEc website: Www.RePEc.org
- from the CESifo website: www.CESifo-group.org/wp




\title{
The Taxation of Passive Foreign Investment Lessons from German Experience
}

\begin{abstract}
The paper evaluates the working of German CFC rules that restrict the use of foreign subsidiaries located in low-tax countries to shelter passive investment income from home taxation. While passive investments make up a significant fraction of German outbound FDI, we find that German CFC rules are quite effective in restricting investments in low-tax jurisdictions. We find evidence that the German 2001 tax reform, which unilaterally introduced exemption of passive income in medium- and high-tax countries, has led to some shifting of passive assets into countries for which the exemption was previously limited.
\end{abstract}

JEL Code: H25, H73.

Keywords: foreign direct investment, $\mathrm{CFC}$ regulation, passive investment.

\author{
Martin Ruf \\ Mannheim University \\ Faculty of Business Administration \\ 68131 Mannheim \\ Germany \\ martin.ruf@bwl.uni-mannheim.de
}

\author{
Alfons J. Weichenrieder \\ Goethe University Frankfurt \\ Faculty of Economics and Business \\ Administration \\ 60323 Frankfurt (Main) \\ Germany \\ a.weichenrieder@em.uni-frankfurt.de
}

\section{April 2009}

The hospitality and support of the Deutsche Bundesbank Research Center is gratefully acknowledged. The second author gratefully acknowledges financial support from the Deutsche Forschungsgemeinschaft (DFG). We benefited from helpful discussions with Johannes Voget and from comments by participants of the Vienna Workshop on "Taxes and the Financial and Legal Structure of Firms", 7-9 January 2009. 


\section{INTRODUCTION}

The treatment of foreign source income of domestic corporations is one of the main issues in shaping a country's international tax rules. The treatment of dividends received from a foreign subsidiary usually follows one of two approaches. Exemption countries, such as the Netherlands, France, and Belgium, abstain from taxation of those dividends. This reflects a territorial approach to international taxation. Countries like the U.S. or Japan, in contrast, adhere to the residence approach that subjects worldwide repatriated income to domestic taxation. At the same time, these countries provide a credit for foreign dividends. In such a credit system, the foreign dividend is subject to corporate tax when received by the parent, but a tax credit that takes into account taxes paid by the foreign subsidiary on profits that underlie the distributed dividend may be credited. This is called an indirect tax credit, while a tax credit that is granted for foreign withholding taxes on the dividend is called a direct tax credit. Usually, capital-exporting countries that use a credit system provide for both the indirect and the direct credit in cases of a qualifying participation.

One of the problems that may haunt both exemption and credit countries is that domestic firms use low-tax jurisdictions to shelter their income from higher home-country taxation. In the case where the home country runs an exemption system this is self-evident: foreign income earned by a foreign subsidiary and subject to low taxation abroad is exempt from high domestic taxes. In the case of credit countries, there still may be an advantage to low foreign tax rates, as the home tax may be deferred until repatriation of the foreign profit. These tax shelters are generally accepted by home countries of parent corporations in the case of active foreign profits that derive from production, trade, and services. Here a possible argument for doing so is capital import neutrality: foreign subsidiaries of high-tax parents should be given the possibility to compete with native low-tax firms on an equal basis 
(Musgrave 1969). Conversely, subjecting profits of foreign subsidiaries to immediate homecountry taxation may put them at a disadvantage.

While acceptable in the case of active business income abroad, the tax shelter implied by exemption or, to a lesser extent, deferral of home-country taxes is much less palatable for capital-exporting countries if the foreign subsidiary is not competing abroad, but merely acts as an instrument to manage the company group's liquid assets. Most industrialized countries have therefore legislated measures that limit the tax privilege of exemption or deferral in the case of passive investments. The standard approach used in the legislation on controlled foreign companies (CFC rules) by countries such as the U.S., Germany, France, the UK, or Italy is to tax passive investment income of foreign subsidiaries on an accrual basis if some conditions are met; the privilege of exemption or deferral is not extended to these incomes.

While CFC rules are of considerable importance in the legal and theoretical discussions of international corporate tax systems (see, e.g., Weichenrieder 1996 for a theoretical study, and Lang et al. 2004 for a legal comparison of international CFC rules), we are not aware of studies that empirically discuss the effectiveness of CFC rules. ${ }^{1}$ One of the main purposes of this paper is to fill this gap by looking at the German experience.

A first empirical question that arises is about the magnitude and country distribution of passive assets held by German-owned foreign subsidiaries. To what extent do we see a concentration of passive assets in jurisdictions with low corporate taxes? We use several approaches in this paper to shed light on the effectiveness of CFC rules. One approach is to consider whether the way changes in tax rates affect passive investment depends on whether CFC legislation is applicable or not. Our estimates suggest that there indeed is a significant difference. The applicability of the German CFC rules seems to reduce the attractiveness of low local tax rates for passive investment of existing subsidiaries and reduces the incentives to locate subsidiaries in these jurisdictions. Over the last decades there were several changes in

\footnotetext{
${ }^{1}$ A notable exception applies in the case of the analysis of hybrid structures and the U.S. "check the box" rules. See Mutti and Grubert (2006) for details.
} 
the German CFC legislation. One of the changes that we exploit for our purposes is the 2003 reform that ended a tax preference that the $\mathrm{CFC}$ rules had given to intracompany lending as compared to arm's-length investment. We find that the reform had some impact on intracompany loans provided by low-tax subsidiaries, which is in line with expectations. We also make use of the German 2001 reform that extended the exemption method to a wider set of countries.

Overall, the evidence provided in this paper is that German CFC rules have a significant and predictable impact on multinational financing and seem to be an effective measure to limit the shifting of passive assets. We hope that our empirical results have some value for evaluating tax policy options. If CFC rules were rather ineffective, then deferral countries might have a comparative advantage over exemption countries in curbing passive investment abroad. In the case of ineffective CFC rules, an exemption country forgoes taxation of passive income altogether, while in the case of a deferral system home-country taxes are only postponed. Conversely, in the case of effective CFC rules, moving from a deferral system to an exemption of foreign dividend - as currently discussed in the U.S. and the UK - may come at a relatively small cost in terms of additional passive investment abroad.

The reminder of the paper is organized as follows. Section II illustrates the German CFC rules in more detail. Section III describes the data, before Section IV presents the main empirical evidence. Section V concludes.

\section{German CFC Rules}

While resident individuals are taxed on their worldwide income irrespective of whether a dividend has been paid by a German or a foreign corporation, foreign dividends that are received by a German corporation are exempt. In addition, the German corporation is not taxable on retained earnings abroad. Until 2000, the exemption of foreign dividends was restricted to dividends paid from treaty countries. Since $2001,95 \%$ of the dividends received have been exempt, whether a tax treaty applies or not. Since 1972, however, limits to 
exemption have applied due to $\S \S 7-14$ of the German Außensteuergesetz (German Foreign Tax Act). ${ }^{2}$ These CFC rules closely follow the U.S. subpart F legislation introduced in 1964 , and address resident shareholders of controlled foreign corporations investing in low-taxed passive business operations. Under certain conditions, the German rules provide that the pro rata share of low-taxed passive income of a controlled foreign corporation (CFC) abroad is included in the shareholder's income on a current basis, implying that deferral and exemption privileges are denied. German CFC rules are applicable if three requirements are met:

Ownership requirement. In general, the ownership requirement is met if more than 50 percent of ordinary shares or voting rights in the foreign corporation are held directly or indirectly by German resident individuals or companies. ${ }^{3}$

Passive Income. Shareholders of a CFC may be subject to tax on the passive income of the CFC, where the term passive income is defined negatively. Passive income is any income that does not qualify as active under $\S 8$ (1) Außensteuergesetz. Active income is income from agriculture, production, banking and insurance, trade, dividends, and the disposal of shares. Under some additional requirements, also income from services and from renting and leasing is deemed to be active. Income from borrowing and lending of capital is active if the German resident shareholder proves that all of the capital is raised in foreign capital markets from unrelated persons and the same capital is lent to an active foreign business or permanent establishment or to a German business or permanent establishment. As a consequence, interest income from financial activities is generally passive income if capital is raised within the group. Passive capital investment income is a special subcategory of passive income and

\footnotetext{
${ }^{2}$ For a detailed description see Förster and Schmidtmann (2004).

${ }^{3}$ Under certain conditions, also ownership of former residents is considered.
} 
includes income from the possession, administration, and management of cash, receivables, securities, shareholdings, or similar assets. However, such income qualifies as active in the case of foreign subsidiaries in banking and insurance.

Low taxation. German CFC rules only apply to low-taxed passive income. Passive income is considered low-taxed if the tax rate on such income is less than 25 percent (less than 30 percent before 2001).

If the three legal requirements discussed above are all met, the low-taxed passive income is included in the taxable income of the German resident shareholders, but foreign income taxes on the passive income may be deducted or, upon election of the shareholder, credited against the German income or corporation tax. ${ }^{4}$ The German rules also apply to ownership chains, to prevent multitier structures from being used as avoidance measures.

Some German double-tax treaties exempt foreign income regardless of whether this income stems from passive or active investment. In other words, the exemption privilege is not bound to an activity clause, which makes application of German CFC rules difficult. Therefore, in a 1992 revision of the CFC rules, Germany unilaterally declared such treaty protections as not applicable for passive investment income. An exception was introduced for passive capital investment income from intragroup financing activities, where treaty protection still applied for 40 percent of the income. In 2003 treaty protection for ordinary passive income was abolished completely.

\footnotetext{
${ }^{4}$ Passive income up to $€ 80,000$ ( $€ 62,000$ before 2007$)$ may be innocuous if it does not represent more than 10 percent of the CFC's pretax income.
} 


\section{Data Set}

The paper uses the MiDi database of the Deutsche Bundesbank to investigate the impact of German CFC rules. German investors owning foreign subsidiaries are legally required to report on any foreign operation if it meets mild size and ownership requirements. For wholly owned foreign subsidiaries compulsory reporting applies if total assets exceed the equivalent of $€ 3 \mathrm{~m}$. In addition, German investors are obliged to report also on subsidiaries that are held via intermediate companies if ownership ties are sufficiently strong (see Lipponer 2003). Most importantly for our purpose, investors have to report on their foreign subsidiaries' lending to other affiliated firms, on their equity ownership of affiliated companies, and on their financial assets in total..$^{5}$ We complemented the data with information on national characteristics from the World Bank Development Indicators and with tax rate information from PricewaterhouseCoopers, the Bureau of Tax Policy Research at the University of Michigan, KPMG, and other sources.

\section{Empirical Evidence}

\section{IV.1. CFC Rules and the Location of Passive Assets}

In a first step we analyze the allocation of liquid assets in German multinational corporations. More precisely, we highlight the allocation of financial assets abroad that count neither as equity holdings in affiliated companies nor as loans to subsidiaries. The deduction of loans and equity stakes in affiliated corporations avoids double counting of passive investments in the case of ownership chains. The subgroup of passive assets considered will mainly consist of bonds and portfolio equity in arm's-length situations with a moderate or negligible difference between book and market values. These passive assets may be shifted from high-tax to low-tax locations without triggering capital gains taxation. Therefore,

\footnotetext{
${ }^{5}$ This information is missing in most other company balance sheets as available in the Amadeus or Datastream data sets. Previous studies that use MiDi for analyzing tax effects on FDI include Ramb and Weichenrieder (2005) and Büttner and Ruf (2007).
} 
abstracting from CFC legislation, a simple comparison of statutory tax rates suggests that multinationals should hold these transferable passive assets through subsidiaries in low-tax countries and that the benefit of doing so should increase as the tax rate in the low-tax country decreases.

However, adding CFC rules may change the picture. The German rules provide that the passive income earned by controlled foreign corporations abroad is deemed as income of the German parent if the effective taxation of the passive income abroad falls short of a threshold value, which has been $25 \%$ since 2001 (30\% before 2001). While taxes on the passive income paid abroad may be credited against German taxation, the application of the German tax rate (including the relevant local rate) makes this the effective tax rate on the passive investment.

In a first step we look at the country distribution of passive investments, which is illustrated in Table 1. If the CFC regulation is binding and multinationals cannot work around it, we should expect few passive investments in low-tax countries, as the effective rate would not be the host-country rate but the higher German tax rate. Indeed, the descriptive statistics in Table 1, which reports on the passive assets in 23 countries that in 2006 hosted significant shares of passive assets of German multinationals, is largely in line with this. While low-tax jurisdictions like the Cayman Islands, Cyprus, and the Netherland Antilles are on the list, the majority of passive assets are found in major economies with medium or high headline corporate tax rates, like the U.S., France, Canada, the UK, or the Netherlands. ${ }^{6}$

The picture slightly changes if we compare passive investment with the amount of fixed investment and intangibles of German-owned firms in the respective countries. In this

\footnotetext{
${ }^{6}$ A qualification with respect to the effective tax rate may apply because of special holding company regimes in some countries, like the Netherlands. In the Netherlands, subject to certain conditions, since 1997 a group finance company could establish a reserve up to 80 percent of its financial services income. A tax-free withdrawal from the reserve could be made equal to 50 percent of investments in affiliates or up to 100 percent for certain indirect investments. According to a letter of the Dutch government to the European Commission, a total of 87 companies from all over the world have been admitted to this scheme (EU Commission Decision (2003/515/EG)), including Dutch-owned companies. So only a small number will be German-owned. The group-financing-facility reserve deduction has come under attack by the European Commission and will be terminated by 2010 .
} 
case small economies like the Cayman Islands, Jersey, Cyprus, or the Netherland Antilles rank first. For these economies, passive asset holdings of German companies dwarf corresponding real investment by German affiliates.

Table 1: Passive assets outside banking and insurance per country (2006, in million euros)

\begin{tabular}{|c|c|c|c|c|}
\hline \multirow[t]{2}{*}{ Host country } & (1) & (2) & (3) & (4) \\
\hline & $\begin{array}{r}\text { Passive } \\
\text { investment }\end{array}$ & $\begin{array}{l}\text { Fixed investment } \\
\text { and intangibles }\end{array}$ & $\begin{array}{r}\text { Fraction of total } \\
\text { passive } \\
\text { investment }\end{array}$ & $\begin{array}{r}\text { Statutory tax rate } \\
\text { including local } \\
\text { taxes (CT) }\end{array}$ \\
\hline USA & 5345.4 & 125343.3 & $19.0 \%$ & $40.0 \%$ \\
\hline Netherlands & 4904.3 & 7609.1 & $17.4 \%$ & $29.6 \%$ \\
\hline United Kingdom & 2110.8 & 36621.0 & $7.5 \%$ & $30.0 \%$ \\
\hline Cayman Islands & 1616.3 & 66.8 & $5.7 \%$ & $0.0 \%$ \\
\hline Luxembourg & 1585.6 & 4321.5 & $5.6 \%$ & $29.6 \%$ \\
\hline France & 1155.4 & 16133.0 & $4.1 \%$ & $33.3 \%$ \\
\hline Austria & 1104.1 & 10577.4 & $3.9 \%$ & $25.0 \%$ \\
\hline Italy & 1030.1 & 12742.8 & $3.7 \%$ & $37.3 \%$ \\
\hline Australia & 973.8 & 2801.3 & $3.5 \%$ & $30.0 \%$ \\
\hline South Africa & 659.7 & 1277.8 & $2.3 \%$ & $36.9 \%$ \\
\hline Japan & 658.0 & 2175.8 & $2.3 \%$ & $40.7 \%$ \\
\hline Spain & 600.6 & 10633.7 & $2.1 \%$ & $35.0 \%$ \\
\hline Switzerland & 507.1 & 7070.8 & $1.8 \%$ & $29.0 \%$ \\
\hline Hong Kong & 494.2 & 384.9 & $1.8 \%$ & $17.5 \%$ \\
\hline Jersey & 465.2 & 3.5 & $1.7 \%$ & $20.0 \%$ \\
\hline Canada & 403.6 & 9188.2 & $1.4 \%$ & $36.1 \%$ \\
\hline Denmark & 395.5 & 2131.5 & $1.4 \%$ & $28.0 \%$ \\
\hline Netherland Antilles & 382.2 & 0.1 & $1.4 \%$ & $34.5 \%$ \\
\hline Turkey & 344.7 & 2094.2 & $1.2 \%$ & $30.0 \%$ \\
\hline Sweden & 268.0 & 4592.0 & $1.0 \%$ & $28.0 \%$ \\
\hline Cyprus & 266.3 & 107.3 & $0.9 \%$ & $10.0 \%$ \\
\hline South Korea & 251.3 & 1772.9 & $0.9 \%$ & $27.5 \%$ \\
\hline Russia & 245.8 & 4027.5 & $0.9 \%$ & $24.0 \%$ \\
\hline
\end{tabular}

Annotations: In column (1), the table reports the passive investment, defined as the total financial assets net of equity in affiliated firms and lending to affiliated firms, in the country under consideration. We left out firms with an ownership share of the German investor of less than $90 \%$, and excluded unincorporated subsidiaries and subsidiaries in banking and insurance, as these industries are treated differently under the German CFC rules. Column (2) reports the aggregated fixed investment and intangibles of nonfinancial companies. As in the following regressions of Table 2, we censored firms at the 99.9 centile of passive assets.

To investigate whether the German CFC rules restrict German multinationals in their allocation of passive investment, Table 2 reports regression results on the micro level using the panel data described above. As in the descriptive statistics of Table 1, we left out firms with an ownership share of the German investor of less than $90 \%$, and excluded 
unincorporated subsidiaries and subsidiaries in banking and insurance, as these industries are treated differently under the German CFC rules. Generally, the observed units are the German-owned subsidiaries abroad. However, in cases in which a German parent owns more than one subsidiary in a specific country, we aggregated passive investment across observations, i.e., affiliated firms in one country and year were merged and treated as a single observation. This takes into account that affiliated firms located in the same country and owned by the same parent may fail to be independent observations.

While the left-hand variable in the empirical models (1)-(3) of Table 2 is the natural logarithm of passive assets, in models (4)-(6) we use the absolute value of passive assets. Passive investment here is defined as the total financial assets net of equity in affiliated firms and lending to affiliated firms, in the country under consideration. The following right-hand variables appear in Table 2. CT captures the statutory corporate tax rate in the host country. The variable CFC_DUMMY takes on the value one if the country has a statutory tax rate that is below the safe-haven tax rate of the German CFC rules (30\% before $2001,25 \%$ thereafter) and the rules are therefore potentially binding. Clearly, effective CFC rules suggest a negative coefficient for this variable. CT*CFC_Dummy is built by interacting the tax rate and CFC_DUMMY. Similarly, we created CT*(1 - CFC_Dummy). These interaction terms are motivated by the hypothesis that when CFC rules are binding, then we expect that a lower corporate tax rate should have a smaller impact on the attraction of passive assets than when the CFC_Dummy is zero. A different way to model the impact of the regulation is by using CT_EFF. This is a tax rate that is constructed under the assumption that the German CFC rules are always binding if the local statutory tax rate falls short of the safe-haven rate. That is, CT_EFF equals CT if $\mathrm{CT}$ is larger than or equal to the safe-haven rate, but equals the applicable German tax rate otherwise. LN(ASSETS) measures a subsidiary's nonfinancial assets (fixed and intangible assets plus working capital). ${ }^{7}$ It is a proxy for firm size, reflecting that larger firms with more real capital may wish to hold larger amounts of liquid assets.

\footnotetext{
${ }^{7}$ A limitation of the German FDI data is that it is not possible to separate tangible and intangible assets.
} 
Table 2: CFC rules and passive assets

\begin{tabular}{|c|c|c|c|c|c|c|}
\hline \multirow[b]{2}{*}{ COEFFICIENT } & \multicolumn{3}{|c|}{ OLS } & \multicolumn{3}{|c|}{ Panel Poisson } \\
\hline & (1) & (2) & (3) & (4) & (5) & (6) \\
\hline CFC_DUMMY & $\begin{array}{l}-0.771^{* * *} \\
(0.17)\end{array}$ & $\begin{array}{l}-1.475^{* * *} \\
(0.47)\end{array}$ & & $\begin{array}{l}-0.819 * * \\
(0.33)\end{array}$ & $\begin{array}{l}-2.589 * * * \\
(0.94)\end{array}$ & \\
\hline $\mathrm{CT}$ & $\begin{array}{l}-3.691^{* * *} \\
(1.10)\end{array}$ & & & $\begin{array}{l}-3.584^{* * *} \\
(1.28)\end{array}$ & & \\
\hline CT*CFC_DUMMY & & $\begin{array}{l}-1.277 \\
(1.62)\end{array}$ & & & $\begin{array}{l}3.038 \\
(3.40)\end{array}$ & \\
\hline $\mathrm{CT}^{*}(1-$ CFC_DUMMY $)$ & & $\begin{array}{l}-4.294 * * * \\
(1.25)\end{array}$ & & & $\begin{array}{l}-5.362 * * * \\
(1.86)\end{array}$ & \\
\hline CT_EFF & & & $\begin{array}{l}-2.834 * * * \\
(0.65)\end{array}$ & & & $\begin{array}{l}-2.774^{* *} \\
(1.34)\end{array}$ \\
\hline LN(ASSETS) & $\begin{array}{l}0.397 * * * \\
(0.023)\end{array}$ & $\begin{array}{l}0.397 * * * \\
(0.023)\end{array}$ & $\begin{array}{l}0.396 * * * \\
(0.023)\end{array}$ & $\begin{array}{l}0.307 * * * \\
(0.032)\end{array}$ & $\begin{array}{l}0.308^{* * *} \\
(0.038)\end{array}$ & $\begin{array}{l}0.309 * * * \\
(0.039)\end{array}$ \\
\hline LN(CORR) & $\begin{array}{l}0.488^{* *} \\
(0.24)\end{array}$ & $\begin{array}{l}0.435^{*} \\
(0.23)\end{array}$ & $\begin{array}{l}0.577 * * \\
(0.24)\end{array}$ & $\begin{array}{l}0.170 \\
(0.30)\end{array}$ & $\begin{array}{l}0.0330 \\
(0.31)\end{array}$ & $\begin{array}{l}0.218 \\
(0.31)\end{array}$ \\
\hline LN(GDPPC) & $\begin{array}{l}0.578 * * * \\
(0.14)\end{array}$ & $\begin{array}{l}0.519^{* * *} \\
(0.15)\end{array}$ & $\begin{array}{l}0.562 * * * \\
(0.15)\end{array}$ & $\begin{array}{l}1.499^{* * *} \\
(0.24)\end{array}$ & $\begin{array}{l}1.591^{* * *} \\
(0.27)\end{array}$ & $\begin{array}{l}1.455^{* * *} \\
(0.21)\end{array}$ \\
\hline $\mathrm{LN}(\mathrm{GDP})$ & $\begin{array}{l}0.0929^{*} \\
(0.052)\end{array}$ & $\begin{array}{l}0.0988^{*} \\
(0.053)\end{array}$ & $\begin{array}{l}0.0720^{*} \\
(0.042)\end{array}$ & $\begin{array}{l}0.186^{* *} \\
(0.085)\end{array}$ & $\begin{array}{l}0.209^{* *} \\
(0.10)\end{array}$ & $\begin{array}{l}0.173^{*} \\
(0.093)\end{array}$ \\
\hline LN(INTEREST) & $\begin{array}{l}-0.0482 \\
(0.091)\end{array}$ & $\begin{array}{l}-0.0604 \\
(0.092)\end{array}$ & $\begin{array}{l}-0.0187 \\
(0.091)\end{array}$ & $\begin{array}{l}0.113 \\
(0.15)\end{array}$ & $\begin{array}{l}0.0756 \\
(0.17)\end{array}$ & $\begin{array}{l}0.100 \\
(0.15)\end{array}$ \\
\hline Observations & 30815 & 30815 & 30815 & 85388 & 85388 & 85388 \\
\hline R-squared & 0.54 & 0.54 & 0.54 & -- & -- & -- \\
\hline
\end{tabular}

Annotations: The dependent variable in (1)-(3) is the log of passive assets, in (4)-(6) the amount of passive assets. Standard errors in parentheses are corrected for clustering within country-year cells for columns (1)-(3) and derived from bootstrapping for (4)-(6). Stars denote $p$-values; *** $p<0.01 ; * * p<0.05$; * $p<0.1$. All estimations include parent fixed effects, and firms are observed during the period 1996-2006 (unbalanced sample). Affiliates in banking and insurance are not included in the sample, since their activities are assumed to be active according to the German CFC rules. In cases in which a German parent owns more than one subsidiary in a specific country, we aggregated passive investment across country-year observations. The data has been censored at the 0.1 percent of the observations with the largest amounts of passive assets.

Finally, we use four variables capturing nontax country characteristics. LN(GDP) measures the log of GDP measured in purchasing power parities. Since tax rates and country sizes have been found to be systematically correlated, ${ }^{8}$ inclusion of this size measure prevents the tax rate from picking up size effects. In addition we use the log of per capita GDP, LN(GDPPC), measured in purchasing power parities. LN(INTEREST) reflects the local bank

\footnotetext{
${ }^{8}$ See, e.g., Weichenrieder (2005).
} 
lending rate, and $\mathrm{LN}(\mathrm{CORR})$ is defined as the logarithm of the Transparency International corruption index, which is constructed with higher values of the index indicating lower corruption. All regressions include a full set of parent fixed effects and year fixed effects, the coefficients of which are not reported.

Column (1) reports results of an OLS regression with CT and CFC_DUMMY as the main variables of interest. As expected, the coefficient for the tax rate is negative, implying that, in general, a higher tax rate is detrimental to the allocation of passive assets. At the same time, CFC_DUMMY is significantly negative, and the coefficient -0.771 implies that the holdings of passive assets are reduced by some $77 \%$ on the subsidiary level if a country is affected by the German CFC rules. ${ }^{9}$

Before we discuss the results for the other covariates, we would like to comment on the tax variables in the other specifications of Table 2. Regression (2) makes use of the interacted variables CT*CFC_Dummy and CT*(1-CFC_Dummy) and drops CT. While both interacted variables are negative, the larger coefficient of CT when the CFC rules are not binding and the insignificant coefficient for low-tax countries confirm the view that the CFC rules are influencing the allocation of passive assets. A peculiarity of the results of model (2) is that the coefficient of CFC_DUMMY is smaller than minus one, suggesting that the CFC rules reduce passive assets by more than one hundred percent, an obvious impossibility. A likely reason for this result is that $\mathrm{CT}$ is a bad proxy for the effective tax on the return on passive assets. While for CT larger than 25\% (30\% before 2001) CT equals the effective tax rate, for smaller CT the effective level jumps to the German level, which for many years was near $40 \%$. It is this discretionary jump in the effective tax rate that should be picked up here and may explain the large absolute value of CFC_DUMMY.

This problem is circumvented in regression (3), where CT_EFF as the only tax variable equals the German corporate tax rate for CT $<25 \%$ (30\% before 2001$)$, and CT else.

\footnotetext{
${ }^{9}$ Since the CFC_DUMMY in principle could simply reflect a nonlinear effect of the tax rate, we also used an unreported specification in which the squared tax rate was used as an additional regressor, which turned out to be insignificant and irrelevant for the significance and value of the CFC_DUMMY coefficient; and the significance and value of CFC_DUMMY were also unaffected by using the log of the tax rate rather than the rate itself.
} 
Using this effective tax rate made CFC_DUMMY insignificant, which seems to support the view that in model (2) it largely picked up the described discontinuity. CFC_Dummy was therefore dropped in (3), where CT_EFF rather than CT is included. The results in column (3) suggest that the effective tax rate - as a combination of local rate and German CFC rules - can be considered as a highly significant driver for the allocation of passive assets.

There are two possible problems with the OLS results presented in columns (1)-(3). First, taking the logarithm of the stock of passive assets forces us to drop a large number of observations with zero passive assets. This may lead to a possible selection bias in the results. ${ }^{10}$ Second, as emphasized by Silva and Tenreyo (2006), estimating a logarithmic or semilogarithmic OLS model may lead to biased estimations if the data is heteroskedastic. As a solution, these authors suggest using a Poisson maximum-likelihood model, and this route has been taken also in subsequent trade studies (e.g., Egger and Larch 2008), where zero bilateral trade between remote countries is a frequent phenomenon.

The results for the Poisson models are presented in columns (4)-(6) of Table 2 and contain the same set of regressors as the OLS models. While the left-hand side is now measured in total passive assets rather than its logarithm, the tax coefficients of the Poisson maximum-likelihood model, as in the previous models, can be interpreted as semielasticities. While some of the absolute values of the tax coefficients are somewhat higher than in the OLS models, the message of the Poisson estimates is very similar, and the results of (4) and (6) are closely comparable to those in (1) and (3) despite the more than doubling of the observations. A difference that appears in column (5) when compared with the respective OLS result in column (2) is that the coefficient of CT*CFC_DUMMY is now positive, but this coefficient comes with a very high standard error.

In all empirical models of Table 2, LN(ASSETS) was introduced to capture that a larger firm with larger real assets may find it worthwhile to have more liquid assets. The data

\footnotetext{
${ }^{10}$ To address the selection problem we also experimented with a Heckman two-stage model, which produced results closely comparable to those presented in Table 2, but our concerns about the appropriateness of the variables used in the selection stage induced us to omit the results.
} 
is compatible with this hypothesis, and the regression suggests that a one percent increase in real assets is associated with an increase in passive investment of some 0.4 percent when estimated by OLS and by 0.3 percent in the Poisson models. LN(GDP) was introduced on the basis that a large host country may invite making more passive investments. This is confirmed, but the coefficient is only weakly significant at the ten percent level. The interest level in the host country, LN(INTEREST), does not appear to be influential for the size of passive investments. LN(CORR) operates as expected: a lower level of corruption (a higher index) increases passive investments. ${ }^{11}$ GDP per capita, which may also reflect the quality of the institutions, had also a consistent and positive effect on passive assets.

While the Poisson estimates solve the problem of zero observations, the results presented in Table 2 still do not model the location decision of German multinationals (as attention is restricted to observed affiliates), but are conditional on the location decision having been taken. Some affiliates may not have been founded just because of low tax rates for passive assets, or because of the applicability of CFC rules. Therefore, as a complement to our results so far, we now look at the factors that influence the location of affiliates with sizable passive assets. ${ }^{12}$ For this purpose we look at the decision problem from the point of view of the German multinationals. One shortcoming of our FDI data is that we have little information about the German parent firm apart from a firm identifier and the industry in which it is operating. We therefore do not attempt to look at the factors that induce German parents to set up affiliates with large passive assets, but look at the decision where to locate these, given that such an affiliate is on record. For a set of 77 countries and 1242 parent firms, we defined an endogenous binary variable that was encoded with the value one if the parent under consideration owned an affiliate with a substantial fraction of passive assets. Given that the German CFC rules may allow affiliates to have ten percent of their income from passive

\footnotetext{
${ }^{11}$ Using the coefficients derived from model (3) implies that improving the corruption index from 4 to 6 (which is roughly equivalent to the difference between Bulgaria and Slovenia) allows one to increase the tax rate by 8 percentage points without detrimental effects on passive assets.

12 This two-step approach was suggested by Manning, Duan, and Rogers (1987) in the absence of exclusion restrictions.
} 
investment if the total income from that source does not exceed a certain absolute limit, we used a ten percent rule for encoding. Therefore observations received the value one if passive assets exceeded ten percent of total assets. Other affiliates and nonexistent affiliates receive the value zero.

The three conditional logit regression results reported in Table 3 [columns (1)-(3)] follow the setup of Table 2, and all tend to confirm the effectiveness of CFC rules for location decisions. The first column reports estimates where CFC_DUMMY and CT appear as tax variables. As in Table 2, they have the expected sign. Both the tax rate and the applicability of the German CFC rules significantly reduce the probability that a country receives a German affiliate with passive assets of more than ten percent of total assets. The specification in column (2) splits up the tax-rate effect according to whether the foreign tax rate triggers applicability of the CFC rules or not. Unlike in Table 2, in both cases a higher tax rate is significantly discouraging. In addition, however, CFC_DUMMY has still a negative effect on the location decision, although significance is only at the ten percent level. Finally, equation (3) uses the effective tax rate CT_EFF as a regressor.

The three models include four country characteristics from previous regression. GDP, GDP per capita, and the corruption index perform in the expected positive way. Unlike in Table 2, the interest level now enters significantly negative in the location equation, possibly reflecting that lower local interest rates indicate a more stable currency.

Columns (4)-(6) include regression with the same set of regressors, but using a simple linear regression OLS with parent fixed effects to determine the relative importance of the various factors. Given that the overall (unconditional) probability for one of the 77 countries of receiving a German affiliate with more than ten percent of passive assets is $2.14 \%$, the coefficient of CFC_Dummy in column (4) indicates that applicability of the CFC rules reduces this probability by some $37 \%$. Using the panel logit results of column (1) and evaluating at the sample mean probability for the location of a passive investment subsidiary yields an even higher effect of $55 \%$, or 1.2 percentage points. 
Table 3: The location of affiliates with passive assets

\begin{tabular}{|c|c|c|c|c|c|c|}
\hline & \multicolumn{3}{|c|}{ Panel logit model } & \multicolumn{3}{|c|}{ Linear probability model } \\
\hline & (1) & (2) & (3) & (4) & (5) & (6) \\
\hline \multirow[t]{2}{*}{ CFC_DUMMY } & $-0.805 * * *$ & $-0.453 *$ & & $-0.00795 * * *$ & 0.00297 & \\
\hline & $(0.11)$ & $(0.27)$ & & $(0.0015)$ & $(0.0055)$ & \\
\hline \multirow[t]{2}{*}{$\mathrm{CT}$} & $-4.116^{* * *}$ & & & $-0.0261 * * *$ & & \\
\hline & $(0.54)$ & & & $(0.0097)$ & & \\
\hline \multirow[t]{2}{*}{ CT*CFC_DUMMY } & & $-4.886 * * *$ & & & $-0.0444 * * *$ & \\
\hline & & $(0.68)$ & & & $(0.011)$ & \\
\hline \multirow[t]{2}{*}{$\mathrm{CT}^{*}(1-$ CFC_DUMMY $)$} & & $-3.439 * * *$ & & & -0.00340 & \\
\hline & & $(0.71)$ & & & $(0.015)$ & \\
\hline \multirow[t]{2}{*}{ CT_EFF } & & & $-1.998 * * *$ & & & $-0.0183 * *$ \\
\hline & & & $(0.47)$ & & & $(0.0073)$ \\
\hline \multirow[t]{2}{*}{ LN(GDPPC) } & $1.187 * * *$ & $1.158 * * *$ & $1.153 * * *$ & $0.0142 * * *$ & $0.0137 * * *$ & $0.0142 * * *$ \\
\hline & $(0.093)$ & $(0.098)$ & $(0.094)$ & $(0.00093)$ & $(0.00093)$ & $(0.00093)$ \\
\hline \multirow[t]{2}{*}{ LN(GDP) } & $0.422 * * *$ & $0.414 * * *$ & $0.382 * * *$ & $0.00907 * * *$ & $0.00888 * * *$ & $0.00916^{* * *}$ \\
\hline & $(0.028)$ & $(0.028)$ & $(0.023)$ & $(0.00058)$ & $(0.00057)$ & $(0.00055)$ \\
\hline \multirow[t]{2}{*}{ LN(INTEREST) } & $-0.168 * *$ & $-0.157 * *$ & $-0.145 * *$ & $-0.00180 *$ & $-0.00169 *$ & -0.00156 \\
\hline & $(0.069)$ & $(0.068)$ & $(0.067)$ & $(0.0010)$ & $(0.0010)$ & (0.00099) \\
\hline \multirow[t]{2}{*}{$\mathrm{LN}(\mathrm{CORR})$} & $0.395 * * *$ & $0.447 * * *$ & $0.460 * * *$ & $0.0113 * * *$ & $0.0119 * * *$ & $0.0116^{* * *}$ \\
\hline & $(0.11)$ & $(0.12)$ & $(0.11)$ & $(0.0016)$ & $(0.0016)$ & $(0.0016)$ \\
\hline Observations & 160409 & 160409 & 160409 & 163472 & 163472 & 163472 \\
\hline $\begin{array}{l}\text { Pseudo R-squared / R- } \\
\text { squared }\end{array}$ & 0.13 & 0.13 & 0.13 & 0.03 & 0.03 & 0.03 \\
\hline
\end{tabular}

Annotations: Columns (1)-(3) report conditional logit estimates with parent fixed effects. Numbers in columns (1)-(3) represent coefficients rather than odds ratios. Standard errors are corrected for clustering at the parent level. Columns (4)-(6) report OLS with standard errors clustered across country-year cells. Stars denote $p$ values: $* * * p<0.01 ; * * p<0.05 ; * p<0.1$. All estimations include parent fixed effects, and firms are observed during the period 1996-2006 (unbalanced sample). Affiliates in banking and insurance are not considered in the sample, since their activities are assumed to be active according to the German CFC rules.

\section{IV.2. Loans to Affiliated Enterprises and CFC Legislation}

In the last section we concentrated on the investment in arm's-length transactions. The present section complements the analysis by looking at intrafirm lending. Most countries allow firms to deduct the interest cost of corporate debt. The advantage of the debt tax shield is larger, the larger the local tax rate is. For this reason, multinational firms have an incentive to allocate debt in high-tax countries and to allocate equity in low-tax ones. A related strategy that may be motivated by international tax rate differentials is the establishment of financial conduit entities in low-tax countries or tax havens. A tax-efficient approach may be to finance 
these companies by equity and have them forward these funds in the form of intracompany loans to high-tax subsidiaries, possibly including the parent firm (see, e.g., Mintz 2004, Weichenrieder and Mintz 2008). As a result, the multinational's interest expenses are taxdeductible in high-tax countries, whereas the taxation of the interest payments in the conduit entity is subject to low or even zero tax rates. Abstracting from countries' antiavoidance measures, the shifting of equity and debt, unlike the shifting of real assets, does not trigger taxation of hidden reserves and should therefore be comparatively straightforward.

However, governments do react to such tax planning strategies. German CFC rules treat the interest income of such conduit entities as passive income, and the German parent of the conduit entity may be subject to German taxation on the passive income abroad. For interest income of such foreign corporations the German statutory tax rate becomes effective unless the conduit entity can provide evidence that the forwarded loans have been exclusively financed on capital markets outside Germany (rather than by receiving equity from the German parent).

To investigate whether the German regulations are binding, we identify all Germanowned subsidiaries for which lending to affiliated enterprises exceeds liabilities. For the rest of the paper we will label these corporations conduit entities with positive net lending (CEPNL). There are two reasons for concentrating on subsidiaries that are net lenders. First, given that interest rates on borrowing and lending are approximately the same, using liabilities to finance lending is not a tax-efficient strategy: in such cases interest payments received and interest payments paid should largely net out (assuming that arm's-length transfer pricing rules are respected), and the resulting profit and thus possible tax savings are near zero. Second, German CFC rules will be applicable in cases where net lending is positive. Conversely, if net lending is negative, we may conclude that all the funds have been raised on foreign capital markets, which implies that German CFC rules were not applicable.

Table 4 offers descriptive statistics on the number of German-owned conduit entities complying with a positive net lending and presents the respective amount of loans to affiliated 
enterprises in 2005. The table includes all countries that in 2005 have hosted more than two CEPNLs. In total this yields 170 cases. The total amount of net lending for these 170 cases is moderate, at least for non-U.S. subsidiaries. In the Netherlands, for example, German-owned subsidiaries accounted for $€ 879 \mathrm{~m}$. of net lending. Among the countries in Table 4 , the only low-tax country according to the definition of the German CFC rules is Ireland. Tax-haven countries, such as the Cayman Islands or the Bermudas, are not used as significant locations for conduit entities in the sample presented here. ${ }^{13}$ Tax incentives for setting up conduit entities may however apply in the cases of the Netherlands and Switzerland. In both countries, holding company regimes apply to certain corporations that may considerably reduce the effective tax rate on interest income (see Weichenrieder and Mintz 2008).

\footnotetext{
${ }^{13}$ For confidentiality reasons we cannot report descriptive statistics if the number of observations per year in a country is lower than three. Hence all countries not represented in the table above may at maximum have two conduit entities with net lending in 2006.
} 
Table 4: Conduit entities with positive net lending by country (2006)

\begin{tabular}{lrrr}
\hline Country & $\begin{array}{c}\text { Lending to affiliated companies } \\
\text { less liabilities (in million euros) }\end{array}$ & $\begin{array}{r}\text { No. of conduit } \\
\text { entities }\end{array}$ & Statutory tax rate \\
\hline USA & 53824 & 58 & 0.4 \\
UK & 3574 & 38 & 0.3 \\
Switzerland & 610 & 31 & 0.29 \\
France & 563 & 30 & 0.3333 \\
Netherlands & 807 & 26 & 0.296 \\
Belgium & 2607 & 12 & 0.3399 \\
Austria & 309 & 10 & 0.25 \\
South Africa & 82 & 9 & 39.6 \\
Luxembourg & 1109 & 8 & 0.2963 \\
Irland & 718 & 7 & 0.125 \\
Spain & 28 & 6 & 0.35 \\
Sweden & 71 & 6 & 0.28 \\
Canada & 405 & 5 & 0.361 \\
Italy & 226 & 5 & 0.3725 \\
Cayman Islands & 4406 & 4 & 0 \\
Singapore & 32 & 4 & 0.2 \\
Australia & 25 & 4 & 0.3 \\
Jersey & 99 & 4 & 20 \\
Finland & 31 & 3 & 0.26 \\
Denmark & 51 & 3 & 0.28 \\
Estonia & 21 & 3 & 0.23 \\
Malta & 243 & 3 & 0.35 \\
\hline \hline Annotions & 53 & 5 \\
\hline
\end{tabular}

Annotations: The table reports on those conduit entities for which net lending (lending to affiliated companies minus total liabilities) is positive. We left out firms with an ownership share of the German investor of less than $90 \%$, and excluded unincorporated subsidiaries and subsidiaries in banking and insurance, as these industries are treated differently under the German CFC rules. For confidentiality reasons, we do not report on countries with less than three qualifying subsidiaries.

Table 5: The treatment of interest income from lending to affiliated companies (positive net lending)

\begin{tabular}{lll}
\hline \hline \multirow{2}{*}{$\begin{array}{l}\text { Treaty country with activity clause } \\
\text { and nontreaty countries }\end{array}$} & $\begin{array}{l}\text { Treatment of passive income } \\
\text { subsidiaries } \\
1993-2002\end{array}$ & derived from lending to \\
\cline { 2 - 3 } $\begin{array}{l}\text { Treaty country without activity } \\
\text { clause }\end{array}$ & $\begin{array}{l}\text { German parent is taxed on total } \\
\text { interest income of the foreign } \\
\text { subsidiary }\end{array}$ & $\begin{array}{l}\text { German parent is taxed on total } \\
\text { interest income of the foreign } \\
\text { subsidiary }\end{array}$ \\
& $\begin{array}{l}\text { German parent is taxed on } 60 \\
\text { percent of the interest income of } \\
\text { the foreign subsidiary }\end{array}$ & $\begin{array}{l}\text { German parent is taxed on total } \\
\text { interest income of the foreign } \\
\text { subsidiary }\end{array}$ \\
\hline \hline
\end{tabular}

The effects of the German CFC rules on the number of CEPNLs may be investigated by looking at the 2003 reform. ${ }^{14}$ Table 5 explicates the effect of this reform, which had a

\footnotetext{
${ }^{14} \S 10$ (6) Außensteuergesetz was abolished with effect from fiscal year 2003.
} 
differential effect on conduit entities depending on tax treaty details. The reform implied no change for CEPNLs in cases where the tax treaty contains an activity clause. In pre- and postreform years, the German CFC rules triggered a tax for the German parent (at a rate of approximately $39 \%$ in 2005) if a foreign subsidiary derived interest income from intracompany loans, the loans were not financed on local capital markets, and a low foreign tax rate on the interest income applied. Conversely, if the relevant tax treaty contains no activity clause, then the prereform treatment of the parent implied that only 60 percent of the foreign interest income was subjected to German tax. For the postreform years, the preference given in these cases was lost, and 100 percent of the foreign interest income was subject to German tax. As a result, the reform decreased the incentives to use low-tax countries that enjoy the preference of a double-tax treaty with no activity clause, and from 2003 we should expect to see a diminishing number of conduit entities there. We should add that the reform has affected only a few countries, since Germany has accepted omission of an activity clause only in a limited number of cases, including France, Ireland, Denmark, Finland, Sweden, and Norway, with the most prominent low-tax jurisdiction being Ireland. Indeed, Ireland is the only host country that fell below the $25 \%$ safe-haven rate of the German CFC rules and is enjoying a tax treaty without activity clause.

Table 6 reports descriptive statistics for CEPNLs in Ireland. Overall, German multinationals did not make extensive use of those conduit entities in Ireland, and the maximum number of CEPNLs was nine, reached in 1997. The aggregated amount of loans to affiliated enterprises not financed by liabilities reached a maximum of €978m. in 1996 . Assuming an interest rate of 5\% and a German statutory tax rate of roughly 56\% at that time, the tax savings from using the Ireland CEPNLs may have reached some $€ 22.5 \mathrm{~m}$. $[=€ 978 \mathrm{~m}$. $\times$ $5 \% \times(56 \%-10 \%)]$ in this year. 


\begin{tabular}{crcc}
\hline \hline Year & $\begin{array}{c}\text { Lending to affiliated } \\
\text { companies net of borrowing } \\
\text { (in million euros) }\end{array}$ & $\begin{array}{c}\text { Number of conduit entities } \\
\text { with positive net lending }\end{array}$ & Corporate tax rate \\
\hline 2006 & 718 & 7 & $12.5 \%$ \\
2005 & 619 & 4 & $12.5 \%$ \\
2004 & $*$ & $*$ & $12.5 \%$ \\
2003 & 329 & 4 & $12.5 \%$ \\
2002 & 423 & 7 & $10.0 \%$ \\
2001 & 70 & 6 & $10.0 \%$ \\
2000 & 229 & 5 & $10.0 \%$ \\
1999 & 66 & 6 & $10.0 \%$ \\
1998 & 777 & 7 & $10.0 \%$ \\
1997 & 840 & 9 & $10.0 \%$ \\
1996 & 978 & 7 & $10.0 \%$ \\
\hline \hline
\end{tabular}

Annotations: * Information on less than three observations has to be omitted for confidentiality reasons.

The change in German CFC rules from 2003 onwards was associated with a reduction of the number of conduit entities in Ireland. Table 6 revisits the effect of the 2003 reform by presenting microeconometric evidence. The analysis is based on all subsidiaries of 421 German parents that had at least one CEPNL according to our definition. Each of these subsidiaries is then treated as one observation. The left-hand variable of the regressions is a zero-one indicator, with a value of one if the German-owned subsidiary is a CEPNL, i.e., its lending to affiliated companies is larger than its liabilities. Besides the variables used before, we now also include two new ones. CFC_DUMMY*NOACTI, like CFC_DUMMY, can only be equal to one if the local statutory tax rate is below the German safe-haven rate. Unlike CFC_DUMMY, it is only equal to one if the subsidiary under consideration benefits from the absence of an activity clause in the relevant tax treaty. Since prior to 2003 these subsidiaries received preferential treatment in the German CFC rules, we should expect a positive coefficient, i.e., a higher likelihood of CEPNLs (given inclusion of the variable CFC_DUMMY). Since the preference for low-tax countries without activity clause was dropped for years from 2003, we expect that this positive effect is nullified for this period. To allow identification of this hypothesis we include the variable CFC_DUMMY*NOACTI*POST2003, which equals CFC_DUMMY*NOACTI for 2003 through 2005, but is zero otherwise. 
Table 7: Locating conduit entities with positive net lending

\begin{tabular}{lll}
\hline \hline & Panel logit & $\begin{array}{l}\text { OLS, linear } \\
\text { probability }\end{array}$ \\
\hline CT & -1.664 & -0.0527 \\
CFC_DUMMY & $(1.38)$ & $(0.055)$ \\
& $-0.659^{* * *}$ & $-0.0270^{* * *}$ \\
CFC_DUMMY*NOACTI & $(0.25)$ & $(0.0089)$ \\
& $0.815^{* *}$ & $0.0381^{* * *}$ \\
CFC_DUMMY*NOACTI*POST2003 & $(0.38)$ & $(0.014)$ \\
& $-1.066^{* *}$ & $-0.0577^{* * *}$ \\
LN(CORR) & $(0.52)$ & $(0.021)$ \\
LN(GDP) & $1.002^{* * *}$ & $0.0433^{* * *}$ \\
& $(0.26)$ & $(0.011)$ \\
LN(GDPPC) & -0.0239 & $-0.00336^{*}$ \\
& $(0.056)$ & $(0.0019)$ \\
LN(INTEREST) & $0.643^{* * *}$ & 0.00508 \\
LN(ASSETS) & $(0.22)$ & $(0.0051)$ \\
& $-0.374 *$ & $-0.00847^{* *}$ \\
Pseudo R-squared / R-squared & $(0.21)$ & $(0.0043)$ \\
\hline \hline
\end{tabular}

Annotations: Dependent variable: dummy indicating positive net lending of the subsidiary. Stars denote $p$ values: $* * * p<0.01 ; * * p<0.05 ; * p<0.1$. Conditional logit standard errors are robust and clustered on the parent level; results for the OLS are robust and corrected for clustering within country-year cells. All estimations include time fixed effects and parent fixed effects, and firms are observed during the period 1996-2006 (unbalanced sample). The logit model drops groups with all positive or all negative outcomes; therefore observations differ between models. Banks and insurance firms are not included in the sample, since their activities are assumed to be active according to the German CFC rules.

The regression results presented in Table 7 confirm that German CFC rules affect affiliate behavior. A binding German CFC rule (i.e., a local tax rate below the German safehaven rate) reduces the frequency of CEPNLs, as indicated by the significantly negative coefficient of CFC_DUMMY in the panel logit as well as in a linear probability model. With an average probability of 6.5 percent, both models suggest that binding CFC rules reduce the probability of a German parent owning a CEPNL in a country by some 45 percent.

The coefficient for CFC_DUMMY*NOACTI indicates that - compared with low-tax countries that have an activity clause in their treaty with Germany - low-tax countries that do not face this clause host more CEPNLs. The negative coefficient of 
CFC_DUMMY*NOACTI*POST2003 also shows that the elimination of the CFC preference roughly nullified this effect, with the combined effect of the two variables being insignificantly different from zero. The significance of the coefficients and the opposite signs of these two variables of interest are conserved across different regression specifications, at least at the ten percent level. At the same time, it should be kept in mind that the coefficients for CFC_DUMMY*NOACTI*POST2003 and CFC_DUMMY*NOACTI, unlike those for CFC_DUMMY, are based exclusively on firm observations in Ireland, and the results should therefore be taken with a grain of salt. The model also uses the additional covariates included in previous regressions. The positive coefficient of LN(ASSETS) indicates that CEPNLs tend to be above average size. The coefficients of LN(CORR) and LN(INTEREST) are plausibly indicating that conduit entities are attracted by low corruption and low interest rates.

\section{IV.3. Exemption of Repatriated Passive Income: the 2001 Reform}

As mentioned above, the German double-tax treaties differ with respect to inclusion of an activity clause. The previous subsection has discussed this in connection with the 2003 reform, which changed the tax treatment of intracompany lending conducted through subsidiaries in low-tax countries (i.e., countries below the safe haven rate). The differences in bilateral tax treaties are also relevant for high-tax partner countries, due to the 2001 German tax reform. Before 2001, exemption of dividends paid from treaty countries with activity clause was restricted to dividends from active income, while dividends paid from passive income were taxed by using the credit system. Since 2001, Germany has extended the exemption system unilaterally also to countries that have agreed to an activity clause in the tax treaty (and even to nontreaty countries). Hence, passive investment income repatriated from countries without an activity clause was exempt from German taxation before as well as after 2001, whereas dividends repatriated from countries with an activity clause were tax-exempt in Germany only from 2001 onwards. This tax reform therefore gives us the opportunity to 
investigate the changed incentives in activity-clause countries, using the subsidiaries in countries without a clause as a control group, allowing the use of interactive variables.

As in Section IV.1, we start by using the log of passive investment (excluding loans and equity in affiliated companies) as the left-hand variable in a panel OLS model [columns (1)-(3)]. The treatment group in our natural experiment consists of all the subsidiaries in countries that either have no tax treaty with Germany or have one with an activity clause. For these subsidiaries the German 2001 reform made the tax treatment of passive income more lenient. To identify this effect we created the dummy variable POST_REFORM_W, which takes on the value one in years 2001-2006 if the relevant country has an activity clause or no tax treaty at all. Again, specification (1) starts with a relatively parsimonious empirical model. In line with our hypothesis, the coefficient of POST_REFORM_W is positive and significant, indicating that the reform has made passive investment relatively more attractive in countries that had agreed on an activity clause (or have no tax treaty). Compared to the control group, the reform has increased the amount of passive investments in arm's-length investments by more than 20 percent.

The application of the credit method or the exemption method at the level of the German parent matters more, the lower the tax rate in the host country. Therefore, passive investments in low-tax countries should be more reactive to the tax policy change. To look into this we created yet another dummy by interacting POST_REFORM_W with LOW, a dummy for countries with a tax rate at or below 35 percent, yielding the variable POST_REFORM_W_LOW. Using this variable along with POST_REFORM_W in column (2) leads to a higher level for the coefficient of POST_REFORM_W_LOW than of POST_REFORM_W. Although the inclusion of this split reduces the significance, the size of the estimated coefficients indicates that the change in passive investments occurred mostly in countries with moderate tax rates. This is also suggested by column (3), which reports a significant estimate for POST_REFORM_W_LOW when POST_REFORM_W is dropped. 
Table 8: German tax reform 2001 and passive investment

\begin{tabular}{|c|c|c|c|c|c|c|}
\hline & \multicolumn{3}{|c|}{ OLS } & \multicolumn{3}{|c|}{ Panel Poisson } \\
\hline & (1) & (2) & (3) & (4) & $(5)$ & (6) \\
\hline \multirow[t]{2}{*}{$\overline{\mathrm{CT}}$} & 0.874 & 0.767 & 0.929 & 0.964 & 0.441 & 1.056 \\
\hline & $(0.62)$ & $(0.60)$ & $(0.62)$ & $(1.70)$ & $(2.75)$ & $(1.72)$ \\
\hline \multirow[t]{2}{*}{ POST_REFORM_W } & $0.205 * *$ & 0.0746 & & $0.379 *$ & -0.00539 & \\
\hline & $(0.083)$ & $(0.20)$ & & $(0.21)$ & $(0.31)$ & \\
\hline \multirow[t]{2}{*}{ POST_REFORM_W_LOW } & & 0.156 & $0.206^{* *}$ & & 0.452 & $0.435^{*}$ \\
\hline & & $(0.20)$ & $(0.080)$ & & $(0.34)$ & $(0.23)$ \\
\hline \multirow[t]{2}{*}{ LOW } & & $-0.105^{*}$ & & & -0.177 & \\
\hline & & $(0.059)$ & & & $(0.25)$ & \\
\hline \multirow[t]{2}{*}{$\mathrm{LN}(\mathrm{CORR})$} & 0.0909 & 0.104 & 0.0817 & 0.261 & 0.269 & 0.247 \\
\hline & $(0.098)$ & $(0.099)$ & $(0.100)$ & $(0.28)$ & $(0.25)$ & $(0.31)$ \\
\hline \multirow[t]{2}{*}{ LN(GDP) } & 0.00502 & -0.145 & 0.132 & 4,565 & 5,005 & 4,790 \\
\hline & $(1.83)$ & $(1.81)$ & $(1.81)$ & $(6.12)$ & $(5.87)$ & $(6.10)$ \\
\hline \multirow[t]{2}{*}{ LN(GDPPC) } & 2.124 & 2.241 & 2.014 & -3.493 & -3.862 & -3.671 \\
\hline & $(1.88)$ & $(1.85)$ & $(1.86)$ & $(6.89)$ & $(6.12)$ & $(6.16)$ \\
\hline \multirow[t]{2}{*}{ LN(INTEREST) } & 0.155 & 0.157 & 0.144 & 0.0213 & 0.0355 & 0.0157 \\
\hline & $(0.11)$ & $(0.11)$ & $(0.11)$ & $(0.26)$ & $(0.21)$ & $(0.19)$ \\
\hline \multirow[t]{2}{*}{ LN(ASSETS) } & $0.203 * * *$ & $0.204^{* * *}$ & $0.203 * * *$ & $0.106^{* *}$ & $0.105^{* *}$ & $0.105^{* *}$ \\
\hline & $(0.036)$ & $(0.036)$ & $(0.036)$ & $(0.042)$ & $(0.044)$ & $(0.044)$ \\
\hline Observations & & & 21657 & 35185 & 35185 & 35185 \\
\hline R-squared & 0.85 & 0.85 & 0.85 & -- & -- & -- \\
\hline
\end{tabular}

Annotations: Dependent variable is the log of passive assets in columns (1)-(3), and the absolute value of passive assets in (4)-(6). OLS columns report robust standard errors, corrected for clustering within country-year cells. Poisson standard errors are derived from bootstrapping. Stars denote $p$-values: $* * * p<0.01 ; * * p<0.05$; * $p<0.1$. All estimations include firm and time fixed effects. Firms are observed during the period 1996-2005 (unbalanced sample). Banks and insurance firms are not included in the sample.

The same objections against application of OLS models that have been quoted in Section V.1 could be raised here. Therefore, we follow our previous approach and complement the OLS estimates with the respective panel Poisson models. Like the OLS models, the Poisson models (4)-(6) suggest that the countries that have benefited from the 2001 extension of the exemption privilege have received additional passive assets compared to other countries. While the estimated coefficients are roughly twice as high as those in columns (1)-(3), they also come with a higher standard error for the tax variables.

\section{Summary and Conclusions}

CFC rules, which are designed to curb the tax revenue losses due to the outflow of passive investments into low-tax countries, are part of the international tax systems of most developed 
countries. So far there has been almost no empirical work on the effects of these rules. In this paper we have tried to fill this gap by looking at German experience. Overall, the German past experience suggests that $\mathrm{CFC}$ rules seem to enable even a high-tax country to significantly inhibit the migration of passive assets into low-tax jurisdictions. Based on a comprehensive database of German FDI, we found that offshore tax-haven countries - the Cayman Islands, Barbados, and the like - are not able to attract major amounts of passive investment or a large number of financing subsidiaries. Neither are these offshore jurisdictions particularly attractive for the location of conduit entities that are equity-funded and grant these funds to affiliated companies by granting loans.

Our empirical work for the first time provides microeconometric evidence on the working of the German CFC rules. One piece of empirical evidence for the effectiveness of the rules is that, while a lower local tax rate in general attracts German passive investment, this effect is lower for countries for which the rules are applicable, since their local rate is below the safe-haven rate. There is also some evidence that the German 2003 revision of the CFC rules, which ended a tax preference for conduit entities in some treaty countries, was successful in curbing passive investments in the form of intracompany loans. Finally, this paper looked at the 2001 tax reform, which unilaterally introduced the exemption of foreign dividends when received by a German corporation. While prior to the reform dividends from various treaty countries were exempt only in the case of an active business abroad, the reform introduced exemption even for dividends paid from passive investment income (provided the CFC rules are not applicable). We find evidence that this legislation has measurably increased the passive investment in the countries that profit from the reform. This may be interesting information for countries like the U.S. and Japan, which are currently discussing the move from a credit system of international taxation to an exemption system. 


\section{Bibliograpy}

Altshuler, R., and H. Grubert. 2003. Repatriation taxes, repatriation strategies and multinational financial policy. Journal of Public Economics 87: 73-107.

Büttner, T., and M. Ruf. 2007. Tax Incentives and the location of FDI: Evidence from a panel of German multinationals. International Tax and Public Finance 14: 151-164.

Egger, P., and Larch, M. 2008. Interdependent preferential trade agreement memberships: an empirical analysis. Journal of International Economics 76: 384-399.

Förster, D., and G. Schmidtmann. 2004. CFC legislation in Germany. Intertax: 476-486.

Lang, M., H.-J. Aigner, U. Scheuerle, and M. Stefaner. 2004. CFC legislation, tax treaties and EC law. Wien: Linde.

Lipponer, A. 2003. Deutsche Bundesbank's FDI Micro Database. Schmollers Jahrbuch Zeitschrift für Wirtschafts- und Sozialwissenschaften 123: 593-600.

Manning, W.G., N. Duan, and W.H. Rogers. 1987. Monte Carlo evidence on the choice between sample selection and two-part models. Journal of Econometrics 35: 59-82.

Mintz, J.M. 2004. Conduit entities: implications of indirect tax-efficient financing structures for real investment. International Tax and Public Finance 11: 419-434.

Musgrave, P.B. 1969. United States taxation of foreign investment income: issues and arguments. Cambridge (MA): International Tax Programm, Harvard Law School.

Mutti, J. and H. Grubert. 2006. New developments in the effect of taxes on royalties and the migration of intangible assets abroad. Paper prepared for the NBER/CRIW Conference on International Service Flows, Washington D.C., 28 April 2006.

Ramb, F., and A.J. Weichenrieder. 2005. Taxes and the financial structure of German inbound FDI. Review of World Economics 141: 670-692.

Santos Silva, J.M.C. and S. Tenreyro (2006), The log of gravity, Review of Economics and Statistics 88, 641-658.

Weichenrieder A.J., and J. Mintz. 2008. What determines the use of holding companies and ownership chains? Oxford University Centre for Business Taxation, Working Paper 0803.

Weichenrieder, A.J. 1996. Anti-tax-avoidance provisions and the size of foreign direct investment. International Tax and Public Finance 3: 67-81.

Weichenrieder, A.J. 2005. (Why) Do we need corporate taxation? Proceedings of OeNB Workshops No.6 - Capital Taxation after EU Enlargement 60-72. 


\section{CESifo Working Paper Series}

for full list see www.cesifo-group.org/wp

(address: Poschingerstr. 5, 81679 Munich, Germany, office@cesifo.de)

2561 Carsten Hefeker, Taxation, Corruption and the Exchange Rate Regime, February 2009

2562 Jiahua Che and Gerald Willmann, The Economics of a Multilateral Investment Agreement, February 2009

2563 Scott Alan Carson, Demographic, Residential, and Socioeconomic Effects on the Distribution of $19^{\text {th }}$ Century US White Statures, February 2009

2564 Philipp Harms, Oliver Lorz and Dieter Urban, Offshoring along the Production Chain, February 2009

2565 Patricia Apps, Ngo Van Long and Ray Rees, Optimal Piecewise Linear Income Taxation, February 2009

2566 John Whalley and Shunming Zhang, On the Arbitrariness of Consumption, February 2009

2567 Marie-Louise Leroux, Endogenous Differential Mortality, Non-Contractible Effort and Non Linear Taxation, March 2009

2568 Joanna Bęza-Bojanowska and Ronald MacDonald, The Behavioural Zloty/Euro Equilibrium Exchange Rate, March 2009

2569 Bart Cockx and Matteo Picchio, Are Short-Lived Jobs Stepping Stones to Long-Lasting Jobs?, March 2009

2570 David Card, Jochen Kluve and Andrea Weber, Active Labor Market Policy Evaluations: A Meta-analysis, March 2009

2571 Frederick van der Ploeg and Anthony J. Venables, Harnessing Windfall Revenues: Optimal Policies for Resource-Rich Developing Economies, March 2009

2572 Ondřej Schneider, Reforming Pensions in Europe: Economic Fundamentals and Political Factors, March 2009

2573 Jo Thori Lind, Karl Ove Moene and Fredrik Willumsen, Opium for the Masses? Conflict-Induced Narcotics Production in Afghanistan, March 2009

2574 Silvia Marchesi, Laura Sabani and Axel Dreher, Agency and Communication in IMF Conditional Lending: Theory and Empirical Evidence, March 2009

2575 Carlo Altavilla and Matteo Ciccarelli, The Effects of Monetary Policy on Unemployment Dynamics under Model Uncertainty - Evidence from the US and the Euro Area, March 2009 
2576 Falko Fecht, Kjell G. Nyborg and Jörg Rocholl, The Price of Liquidity: Bank Characteristics and Market Conditions, March 2009

2577 Giorgio Bellettini and Filippo Taddei, Real Estate Prices and the Importance of Bequest Taxation, March 2009

2578 Annette Bergemann and Regina T. Riphahn, Female Labor Supply and Parental Leave Benefits - The Causal Effect of Paying Higher Transfers for a Shorter Period of Time, March 2009

2579 Thomas Eichner and Rüdiger Pethig, EU-Type Carbon Emissions Trade and the Distributional Impact of Overlapping Emissions Taxes, March 2009

2580 Antonios Antypas, Guglielmo Maria Caporale, Nikolaos Kourogenis and Nikitas Pittis, Selectivity, Market Timing and the Morningstar Star-Rating System, March 2009

2581 António Afonso and Christophe Rault, Bootstrap Panel Granger-Causality between Government Budget and External Deficits for the EU, March 2009

2582 Bernd Süssmuth, Malte Heyne and Wolfgang Maennig, Induced Civic Pride and Integration, March 2009

2583 Martin Peitz and Markus Reisinger, Indirect Taxation in Vertical Oligopoly, March 2009

2584 Petra M. Geraats, Trends in Monetary Policy Transparency, March 2009

2585 Johannes Abeler, Armin Falk, Lorenz Götte and David Huffman, Reference Points and Effort Provision, March 2009

2586 Wolfram F. Richter, Taxing Education in Ramsey’s Tradition, March 2009

2587 Yin-Wong Cheung, Menzie D. Chinn and Eiji Fujii, China's Current Account and Exchange Rate, March 2009

2588 Alexander Haupt and Silke Uebelmesser, Voting on Labour-Market Integration and Education Policy when Citizens Differ in Mobility and Ability, March 2009

2589 Hans Jarle Kind, Marko Koethenbuerger and Guttorm Schjelderup, Should UtilityReducing Media Advertising be Taxed?, March 2009

2590 Alessandro Cigno, How to Avoid a Pension Crisis: A Question of Intelligent System Design, March 2009

2591 Helmut Lütkepohl and Fang Xu, The Role of the Log Transformation in Forecasting Economic Variables, March 2009

2592 Rainald Borck, Hyun-Ju Koh and Michael Pflüger, Inefficient Lock-in and Subsidy Competition, March 2009 
2593 Paolo M. Panteghini, On the Equivalence between Labor and Consumption Taxation, March 2009

2594 Bruno S. Frey, Economists in the PITS?, March 2009

2595 Natalie Chen and Dennis Novy, International Trade Integration: A Disaggregated Approach, March 2009

2596 Frédérique Bec and Christian Gollier, Term Structure and Cyclicity of Value-at-Risk: Consequences for the Solvency Capital Requirement, March 2009

2597 Carsten Eckel, International Trade and Retailing, March 2009

2598 Gianni De Nicolò and Iryna Ivaschenko, Global Liquidity, Risk Premiums and Growth Opportunities, March 2009

2599 Jay Pil Choi and Heiko Gerlach, International Antitrust Enforcement and Multi-Market Contact, March 2009

2600 Massimo Bordignon and Guido Tabellini, Moderating Political Extremism: Single Round vs Runoff Elections under Plurality Rule, April 2009

2601 Ana B. Ania and Andreas Wagener, The Open Method of Coordination (OMC) as an Evolutionary Learning Process, April 2009

2602 Simon Gächter, Daniele Nosenzo, Elke Renner and Martin Sefton, Sequential versus Simultaneous Contributions to Public Goods: Experimental Evidence, April 2009

2603 Philippe Jehiel and Andrew Lilico, Smoking Today and Stopping Tomorrow: A Limited Foresight Perspective, April 2009

2604 Andreas Knabe, Steffen Rätzel, Ronnie Schöb and Joachim Weimann, Dissatisfied with Life, but Having a Good Day: Time-Use and Well-Being of the Unemployed, April 2009

2605 David Bartolini and Raffaella Santolini, Fiscal Rules and the Opportunistic Behaviour of the Incumbent Politician: Evidence from Italian Municipalities, April 2009

2606 Erkki Koskela and Jan König, Can Profit Sharing Lower Flexible Outsourcing? A Note, April 2009

2607 Michel Beine, Frédéric Docquier and Çağlar Özden, Diasporas, April 2009

2608 Gerd Ronning and Hans Schneeweiss, Panel Regression with Random Noise, April 2009

2609 Adam S. Booij, Bernard M.S. van Praag and Gijs van de Kuilen, A Parametric Analysis of Prospect Theory's Functionals for the General Population, April 2009 
2610 Jeffrey R. Brown, Julia Lynn Coronado and Don Fullerton, Is Social Security Part of the Social Safety Net?, April 2009

2611 Ali Bayar and Bram Smeets, Economic, Political and Institutional Determinants of Budget Deficits in the European Union, April 2009

2612 Balázs Égert, The Impact of Monetary and Commodity Fundamentals, Macro News and Central Bank Communication on the Exchange Rate: Evidence from South Africa, April 2009

2613 Michael Melvin, Christian Saborowski, Michael Sager and Mark P. Taylor, Bank of England Interest Rate Announcements and the Foreign Exchange Market, April 2009

2614 Marie-Louise Leroux, Pierre Pestieau and Gregory Ponthiere, Should we Subsidize Longevity?, April 2009

2615 Ronald MacDonald, Lukas Menkhoff and Rafael R. Rebitzky, Exchange Rate Forecasters' Performance: Evidence of Skill?, April 2009

2616 Frederick van der Ploeg and Steven Poelhekke, The Volatility Curse: Revisiting the Paradox of Plenty, April 2009

2617 Axel Dreher, Peter Nunnenkamp, Hannes Öhler and Johannes Weisser, Acting Autonomously or Mimicking the State and Peers? A Panel Tobit Analysis of Financial Dependence and Aid Allocation by Swiss NGOs, April 2009

2618 Guglielmo Maria Caporale, Roman Matousek and Chris Stewart, Rating Assignments: Lessons from International Banks, April 2009

2619 Paul Belleflamme and Martin Peitz, Asymmetric Information and Overinvestment in Quality, April 2009

2620 Thomas Dohmen, Armin Falk, David Huffman and Uwe Sunde, Are Risk Aversion and Impatience Related to Cognitive Ability?, April 2009

2621 Yin-Wong Cheung and Xingwang Qian, The Empirics of China's Outward Direct Investment, April 2009

2622 Frédérique Bec and Christian Gollier, Assets Returns Volatility and Investment Horizon: The French Case, April 2009

2623 Ronnie Schöb and Marcel Thum, Asymmetric Information Renders Minimum Wages Less Harmful, April 2009

2624 Martin Ruf and Alfons J. Weichenrieder, The Taxation of Passive Foreign Investment Lessons from German Experience, April 2009 